\title{
Diel dynamics of young and small fishes in a side-channel of the River Garonne, France, before and after a late-summer spate
}

\author{
S. Mastrorillo ${ }^{1}$, G.H. Copp ${ }^{2}$ \\ ${ }^{1}$ Laboratoire d'Ecologie des Hydrosystèmes, UMR 5177-CNRS/UPS, Université Paul Sabatier, 118 Route de Narbonne, 31062 Toulouse cedex, \\ France. \\ 2 CEFAS, Salmon \& Freshwater Team, Pakefield Road, Lowestoft, Suffolk NR33 OHT, England.
}

\begin{abstract}
We examined diel patterns in fish distribution, size and relative density in a side-channel of the River Garonne before and after a late-summer spate as part of a study of the role of floodplain wetlands in fish recruitment. Increases in fish size (SL) at night were mostly unaffected by the spate, whereas an increase in fish density at night, not observed prior to the spate, was observed in some species post spate. Microhabitat use was variable at dusk and night before and after the spate, but dawn and daytime microhabitat use were less variable after the spate. Water velocity, macrophytes and ligneous debris were the most important microhabitat variables prior to the spate, but were replaced thereafter by substratum composition and bank slope. Changes in microhabitat electivities were most apparent in abundant species, with shifts in depth, substratum and water velocity preferences in 0+ gudgeon Gobio gobio and 0+ chub Leuciscus cephalus. Our results indicate that habitat suitability (or preference) curves and electivity profiles are influenced by variations in river discharge, emphasizing the importance of using multiple samplings (diel, within-season, between-season) when setting habitat criteria for river management and when assessing the role of floodplain wetlands in fish recruitment.
\end{abstract}

Keywords : backwaters, discharge variability, wetlands, flood plain, inland delta, Point Abundance Sampling, summer spate, canonical correspondence analysis.

\section{Introduction}

Large river flood plains, sometimes referred to as wetlands or inland deltas, are important nursery areas for non-salmonid fishes (Copp 1989, Gozlan et al. 1998), and variations in discharge are known to influence the structure of $0+$ fish communties in such biotopes (Bischoff \& Wolter 2001). However, relatively little is known of the diel dynamics of young and small fishes in these large hydrosystems (sensu Amoros \& Petts 1993). Most of the information on diel behaviour of young fishes in medium and large rivers relates to the main channel only (Mathews 1971, Manteifel et al. 1978, Pavlov et al. 1978, Copp \& Jurajda

\footnotetext{
* Corresponding author :

E-mail: Sylvain.Mastrorillo@cict.fr
}

1993, 1999, Bischoff \& Scholten 1996, Garner 1996, Przybylski 1996, Baras \& Nindaba 1999, 2000, Copp et al. submitted), or lentic bays associated with the main channel (Baras \& Nindaba 1999, 2000). The early, unpublished research of Schröder (1979) in a sidearm of the River Rhein, Germany, was the first known to examine the diel dynamics of $0+$ fishes in a large European floodplain river, followed by some recent work on diel patterns in fish and zooplankton size and density in a side-channel of the River Danube (Copp, Vranovsky, Cerny \& Kovác, unpublished data).

Floodplain annexes are important fish nursery areas (Welcomme 1985, Copp 1989b), but the quantitative contribution of such ecosystems to overall population recruitment remains largely unknown. Estimates of fish density are influenced by changes on light levels over the course of a day in rivers (Sanders 1992, Copp \& Jurajda 1993, 1999) and in lakes (e.g. Hanych et al.

Article available at http://www.limnology-journal.org or http://dx.doi.org/10.1051/limn/2005001 
1983, Tischler et al. 2000). Therefore, it is necessary to understand this variability when investigating the contribution of river wetlands to overall fish recruitment. Microhabitat use and prey selection have also been found to vary with time of day (Garner 1996, Copp, Spatari, Turmel, Enot unpublished), so evaluations of resource use should include both night and day samples, such has been suggested for the creation of habitat suitability curves (Mathur et al. 1985, Roussel et al. 1999).
The aim of the present study was to investigate the diel dynamics of non-salmonid fishes in a side-channel of the River Garonne during late summer, with emphasis on relative density, size-structure, dispersion patterns, and microhabitat use within the side-channel and possible interactions with the main channel. An unexpected spate allowed us to evaluate the short-term impact of such a hydrological event on diel dynamics in late summer. Our specific objectives were to : 1) test for differences in the relative densities and size of fish

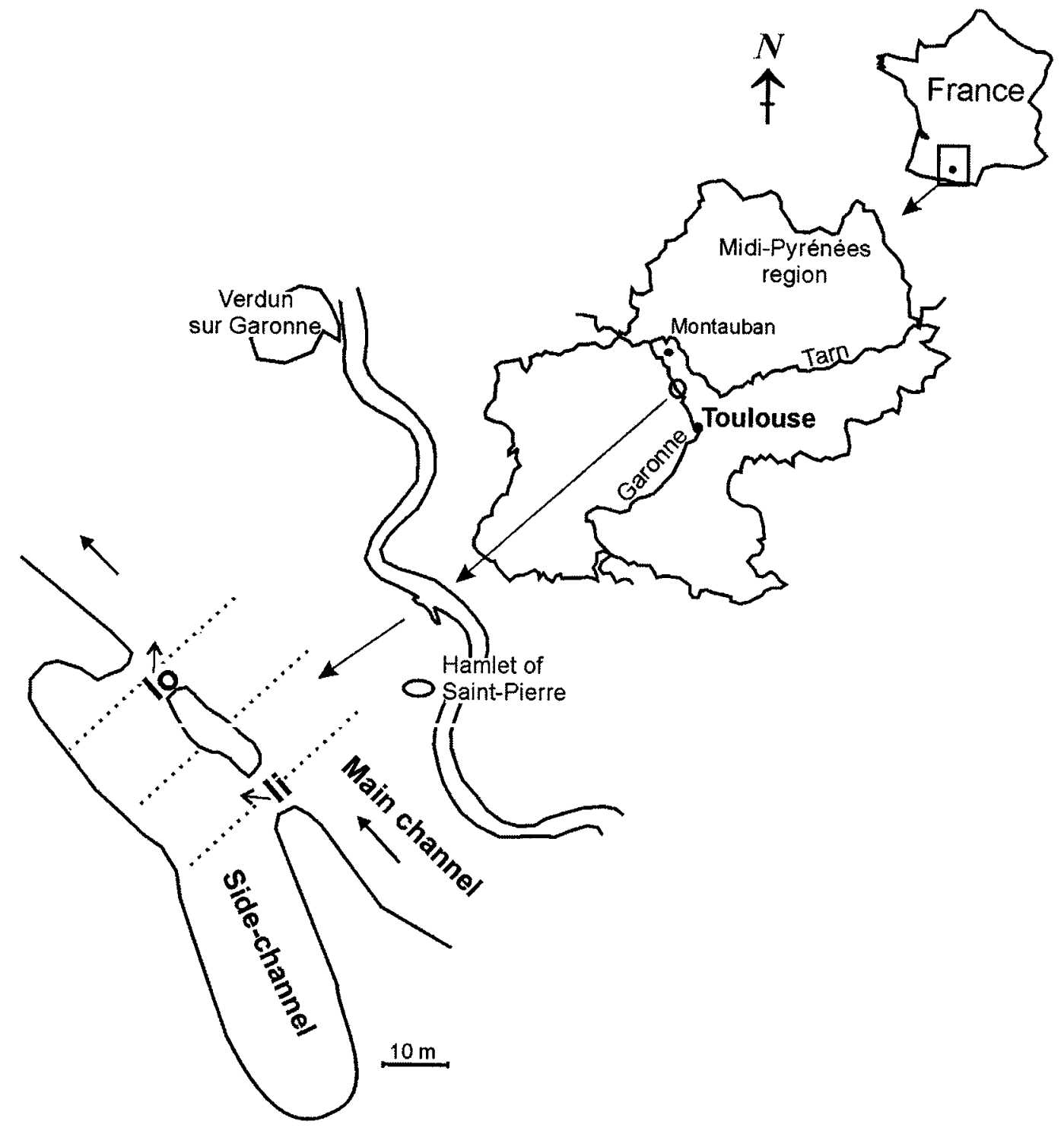

Fig. 1. Map of the River Garonne, France, and the study site, with the upstream inlet interface (Ii) and the downstream outlet interface (Io) of the downstream section of the side-channel with the main channel. (Dotted lines: 23-24 September transects). 
species between intervals of day (dawn, day, dusk, night) ; 2) determine whether fish dispersion, density and size differed according to location, relative to the main channel, over the diel cycle and after a spate ; and 3 ) identify changes in composite microhabitat use and interspecific associations before and after the spate.

\section{Study area}

The River Garonne's source is the Maladetta's glacier (Spain), and the river disappears into « Toro's hole » at $2050 \mathrm{~m}$ altitude. The river reappears in the « Val d'Aran » at $1872 \mathrm{~m}$ altitude and flows for $575 \mathrm{~km}$ discharging into the Atlantic Ocean at its confluence in the Gironde estuary. The mean annual rainfall (based on data from Météo France for 1954 to 1990, Toulouse-Blagnac site) is $612.7 \mathrm{~mm}$, and the mean daily temperature is $5.4^{\circ} \mathrm{C}$ (data from January), which is the coldest month and $21.9^{\circ} \mathrm{C}$ in July (the warmest month). The mean yearly temperature is $13.3^{\circ} \mathrm{C}$ (Bengen 1992). Relative to other French rivers (e.g. Seine and Rhône), the Garonne is amongst the least managed, still possessing most of its wild character, including a relatively natural hydrological regime. The river bed is unstable, which contributes to the creation of sidearms and oxbows (Décamps \& Naiman 1989 ; Belaud et al. 1990) especially in the middle part of the Garonne (from Toulouse to the Tarn confluence). In this section of about $80 \mathrm{~km}$, our study site was the downstream part $(120 \mathrm{~m}$ long ; mean width $=15 \mathrm{~m})$ of a former braided channel on the left bank of the Garonne near the hamlet of Saint-Pierre, Department of Tarn-et-Garonne (Figure 1). This partially-abandoned channel consisted of a large downstream connection with the main channel. The confluence of the main channel and the side-arm included a gravel and pebble island, created by an in-flowing stream from the main channel (interface $1, \mathrm{Ii}$ ) and an out-flowing stream below the island from the side-arm to the main channel (interface 2, Io).

\section{Material and methods}

Hydrological data were acquired from the national hydrological database (French Ministry of the Environment). We extracted a 7-year series of mean daily discharges from this database (from January 1994 to July 2000) for the site of Verdun sur Garonne, situated at $3 \mathrm{~km}$ downstream of the study site (Fig. 2). The hydrological data (Fig. 2A) demonstrate clearly that the middle section of the Garonne has a characteristic pluvio-nival regime, with the highest flows during spring periods (snow melt of Pyrenees Mountains). However, it is not unusual to observe small spates after storms during the low flow period of summer (from mid-August to the end of September), with a three-to-five fold increase in discharge over the base flow (Fig. 2B). Mean daily discharge was about $49 \mathrm{~m}^{3} \cdot \mathrm{s}^{-1}$ during the two 24-h cycles of sampling (respectively 48.7 and $49.3 \mathrm{~m}^{3} \cdot \mathrm{s}^{-1}$ ), which took place on 7-8 and on $23-24$ September 1998. Between these two cycles, the main channel flow reached $275 \mathrm{~m}^{3} \cdot \mathrm{s}^{-1}$ (annual mean flow : $230 \mathrm{~m}^{3} \cdot \mathrm{s}^{-1}$ ). During this summer spate, the study site was inaccessible due to high water velocities, water depth increased by at least $50 \mathrm{~cm}$, the sand and pebble bank was submerged, and the water was very turbid.

Sampling was undertaken in the side-arm using Point Abundance Sampling by electrofishing (Persat \& Copp 1989), with a portable DEKA electrofishing unit modified for small fishes (anode of $10 \mathrm{~cm}$ diameter ; see Copp \& Garner 1995). Each point sample was assumed to be $\approx 0.071 \mathrm{~m}^{2}$ (Copp 1989a), though this area will vary according to water conductivity (Cuinat 1967). On 7-8 September, 30 sampling points were selected haphazardly (point of the finger, arm outstretched, with eyes closed) during each of four sampling excursions (hours CET) : day (14:00), dusk (20:00), night (02:00), and dawn (07:00), with the moon being between full and waning gibbosus. On 23 September 30 sampling points were haphazardly dispersed along three transects (10 points per transect (Fig. 1) ; sampling took place at (hours CET) : day (13:00), dusk (20:00), night (02:00), and dawn (08:00), with the moon being between new and waxing crescent. Sampling was generally undertaken from a dingy, though some points were so shallow that sampling was undertaken by foot. The sampling technique is described in detail in Copp \& Penáz (1988), Copp \& Garner (1995) and Gozlan et al. (1998).

At each point sample, the fishes were identified, measured for standard length (SL) and returned to the water (i.e. fishes $\geq 1+$ ), with a sub-sample of each species preserved in $4 \%$ formaldehyde for subsequent dietary analysis (S. Mastrorillo, unpublished). Habitat character was then evaluated using 3 quantitative and 7 semi-quantitative environmental variables : width of the side-arm (m), distance from the nearest bank $(\mathrm{m})$, depth $(\mathrm{cm})$, bank slope, silt $(<0.06 \mathrm{~cm})$, sand $(0.06-0.2$ $\mathrm{cm})$, pebbles $(0.2-2.0 \mathrm{~cm})$, gravel $(2.0-6.0 \mathrm{~cm})$, cobbles $(>6.0 \mathrm{~cm})$, ligneous structures, macrophytes, periphyton, and water velocity. Distance from bank and depth were measured with a graduated dip-net pole, except for distances $>3 \mathrm{~m}$ for which visual estimates were made using dingy-lengths as the estimator. 

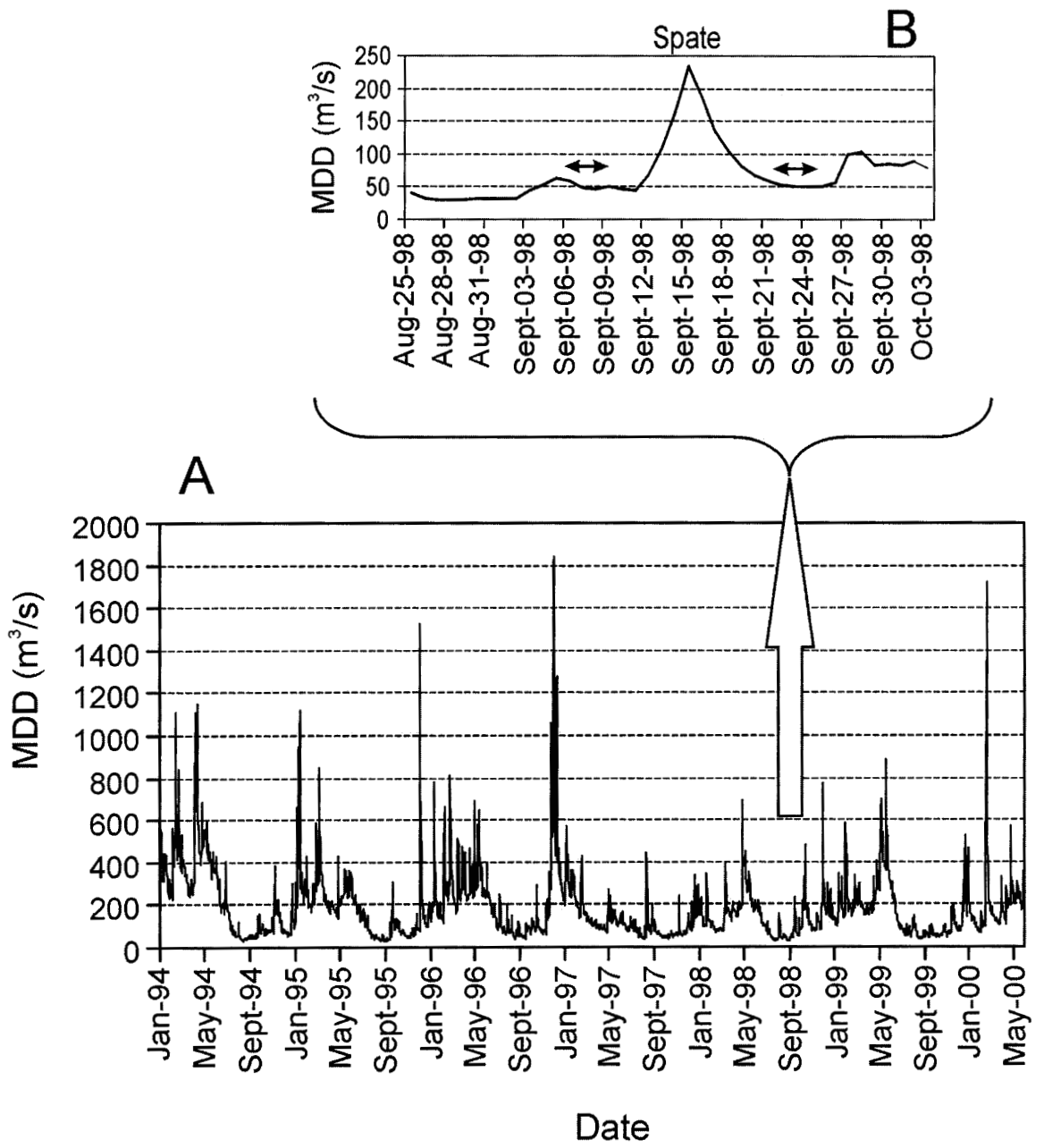

Fig. 2. A) Mean Daily Discharge (MDD) in the River Garonne between January 1994 and May 2000, with B) MDD for the period prior to and after the spate on 14-15 September 1998 (the double arrows indicate the 24-h sampling periods on 7-8 and 23-24 September 1998).

Bank slope was depth divided by distance from bank. Bottom substratum (silt, sand, pebbles, gravel) was evaluated as a percentage of the area sampled (i.e. $\approx$ $0.071 \mathrm{~m}^{2}$ ). Ligneous structures (branches, logs, trunks, roots) within the sample area were counted in a manner similar to that described by Kinsolving \& Bain (1990) but on a scale of 1-10, with all values $>10$ attributed a value of 10 . Bottom substratum types, macrophytes (submerged, floating and emergent), and periphyton were measured as a percentage of the area sampled at the point. Water velocity was measured semi-quantitatively using a calibrated dip-net ; no movement of the net indicated no flow, slow ballooning of net indicated weak flow $\left(<5 \mathrm{~cm} \cdot \mathrm{s}^{-1}\right)$, moderate balloon- ing indicated a moderate flow $\left(5<\mathrm{V}<10 \mathrm{~cm} \cdot \mathrm{s}^{-1}\right)$ and fast ballooning of the net indicated faster flow $(>10$ $\left.\mathrm{cm} \cdot \mathrm{s}^{-1}\right)$.

For data analysis, fish relative density was calculated as the number of specimens captured per total surface area sampled (Copp 1989a, 1989b, Gozlan et al. 1998), with chub Leuciscus cephalus classed as 'small', i.e. non-piscivorous ( $<100 \mathrm{~mm} \mathrm{SL})$, and potentially 'piscivorous' ( $\geq 100 \mathrm{~mm}$ SL) as per Mann (1976). Comparisons of relative densities between sampling intervals were made using the Friedman test. Differences in mean SL were tested using analysis of variance (ANOVA). Dispersion was evaluated using 
Green's (1966) index, which is considered the only such index that is little influenced by differences in sample number (Elliot 1977) : ID $=\left(s^{2} \bar{l}\right)-1 / n \bar{l}-1$, where $\mathrm{s}^{2}$ is the variance, $\bar{l}$ is the mean and $\mathrm{n}$ is the number of samples.

Composite microhabitat use by $0+$ fishes in the sidechannel (interface and main channel data from 23-24 September excluded) on the two dates was assessed using canonical correspondence analysis (CCA, ter Braak 1986), whereby species occurring in $=3 \%$ of samples were retained in the analyses. The variables were categorised in preparation for analysis (Chessel et al. 1987) as follows : distance from bank $(<3,4-6,7-$ 9, 10-12, 13-21 m), depth $(<0.2,0.2-0.39,0.4-0.59$, 0.6-0.79, 0.8-0.95 m), bank slope (0-0.05, 0.051-0.10, $0.11-0.15,>0.15$ ), water velocity (nul, weak $\left[<5 \mathrm{~cm} \cdot \mathrm{s}^{-}\right.$ $\left.{ }^{1}\right]$, medium [5-10 $\left.\mathrm{cm} \cdot \mathrm{s}^{-1}\right]$, fast [ $\left.\left.>10 \mathrm{~cm} \cdot \mathrm{s}^{-1}\right]\right)$, silt, sand, gravel, cobbles (absent, 1-33, 34-66, 67-100\%), periphyton (absent, present), macrophytes/ligneous (absent, present). The gradients generated were the basis for succinctly describing and visualising the differential habitat preferences (niches) of taxa through a biplot ordination diagram (ter Braak \& Verdonschot, 1995). Microhabitat electivities were calculated for each date (all sampling times combined) as the difference between the frequency of a species in the group of samples having that category of environmental variable and the frequency of that species in all the samples. The index varies from +0.5 (preference) to 0.5 (avoidance).

\section{Results}

The most abundant species of young fish encountered were bitterling Rhodeus sericeus, gudgeon Gobio gobio, barbel Barbus barbus and small chub (Fig. 3). The observed sizes suggest that the vast majority of specimens captured were 0+ (except SL>100mm chub). Prior to the spate, under a nearly full moon, overall relative density was highest in the initial day sample and remained low thereafter, with overall dispersion ranging little and approaching randomness $(0)$. However, significantly larger gudgeon and small chub were observed (Fig. 4) at dusk and night, suggesting size-related migrations between the side-channel and elsewhere without an overall change in density. Large chub were present in low abundance (1-2 individuals captured) each interval on 7-8 September but none were captured on 23-24 September.

After the spate, under a nearly fullness sky, overall fish density in the side-channel increased significantly at night (Friedmans, $\mathrm{P}=0.04$ ), with non-significant in- creases in the main species ; contagion in the sidechannel increased from day to dawn. At the interface between the side and main channels, significantly higher densities and greater contagion were found at dusk, suggesting a movement of shoals towards the side-channel. Densities in the main channel varied little, but the fish became more clumped. On 23-24 September, barbel size in the main channel was greatest at night, with few specimens observed elsewhere (Fig. 4). Gudgeon size in the main and side channels was greatest at dusk, but with no apparent diel pattern except in the side-channel. The pattern of size variation in small chub of the side-channel on 7-8 September was repeated on 23-24 September, but was less apparent in the interface and showing a decreasing tendency in the main channel (Fig. 4).

Composite microhabitat use before the spate was influenced most (longest vector, ter Braak \& Verdonschot 1995) by the presence of physical structures (macrophytes/ligneous debris), periphyton, water velocity and $\%$ gravel in the substratum in decreasing order (Fig. 5). Dawn and daytime microhabitat use was generally similar (overlap and similar orientation of ellipses, Thioulouse \& Chessel 1992), whereas dusk and night-time habitat use, particularly in common bream Abramis brama and bleak Alburnus alburnus, was characterized by greater distances from steeper banks and a greater proportion of physical structures within elevated water velocities (Fig. 5). After the spate, microhabitat use was characterised by bank slope and substratum types, with water velocity being particularly important in defining restricted daytime use thereof (Fig. 4). Bank slope and distance from bank appear to be responsible for the greater variation at dawn and night, with barbel preference for cobbles/blocks characterizing the variability at dusk.

Changes in composite microhabitat use in barbel after the spate were mainly a shift in preference for deeper areas away from the bank (Fig. 6). In bitterling, the change was mainly to a higher proportion of sand, as was the case for silver bream A. bjoerkna, which also demonstrated elevated preferences for shallow depths and bank slopes. Small chub also shifted to greater amounts of sand, but also silt, with an avoidance of the elevated water velocities preferred before the spate. Crucian carp Carassius carassius preferred greater depths after the spate and became indifferent to substratum. Both roach Rutilus rutilus and gudgeon preferred greater distances from the bank (Fig. 6), but with increased proportions of gravel in roach and decreased proportions of gravel and cobbles/blocks in gudgeon. 


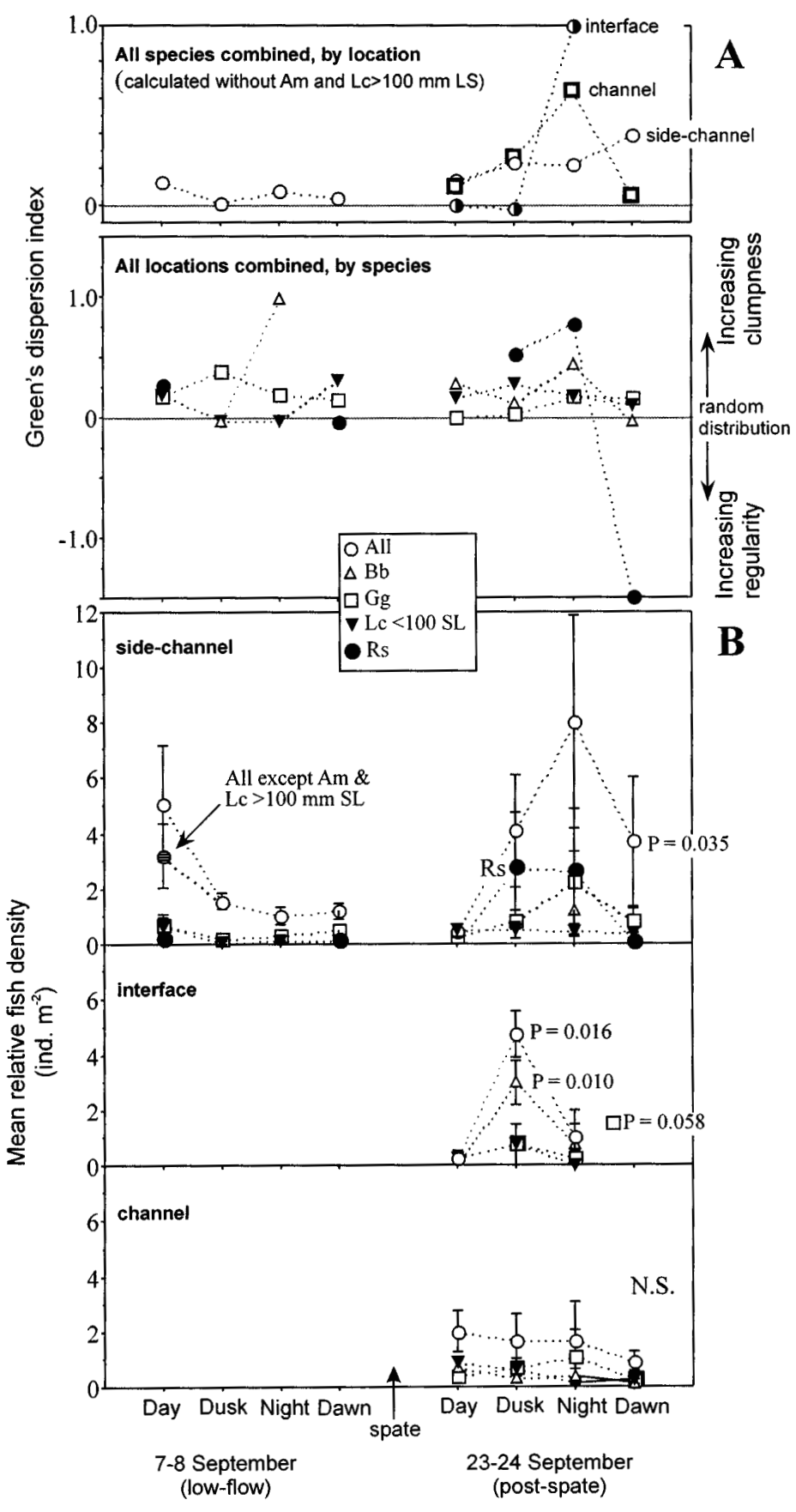

Dates in 1998

Fig. 3. A) Fish dispersion (Green's index) and B) mean relative densities (ind $\cdot \mathrm{m}^{2}$ ) at four intervals over two 24-h periods in a side-channel, the adjacent main channel and the interface between the two, in the River Garonne during late summer of 1998. 


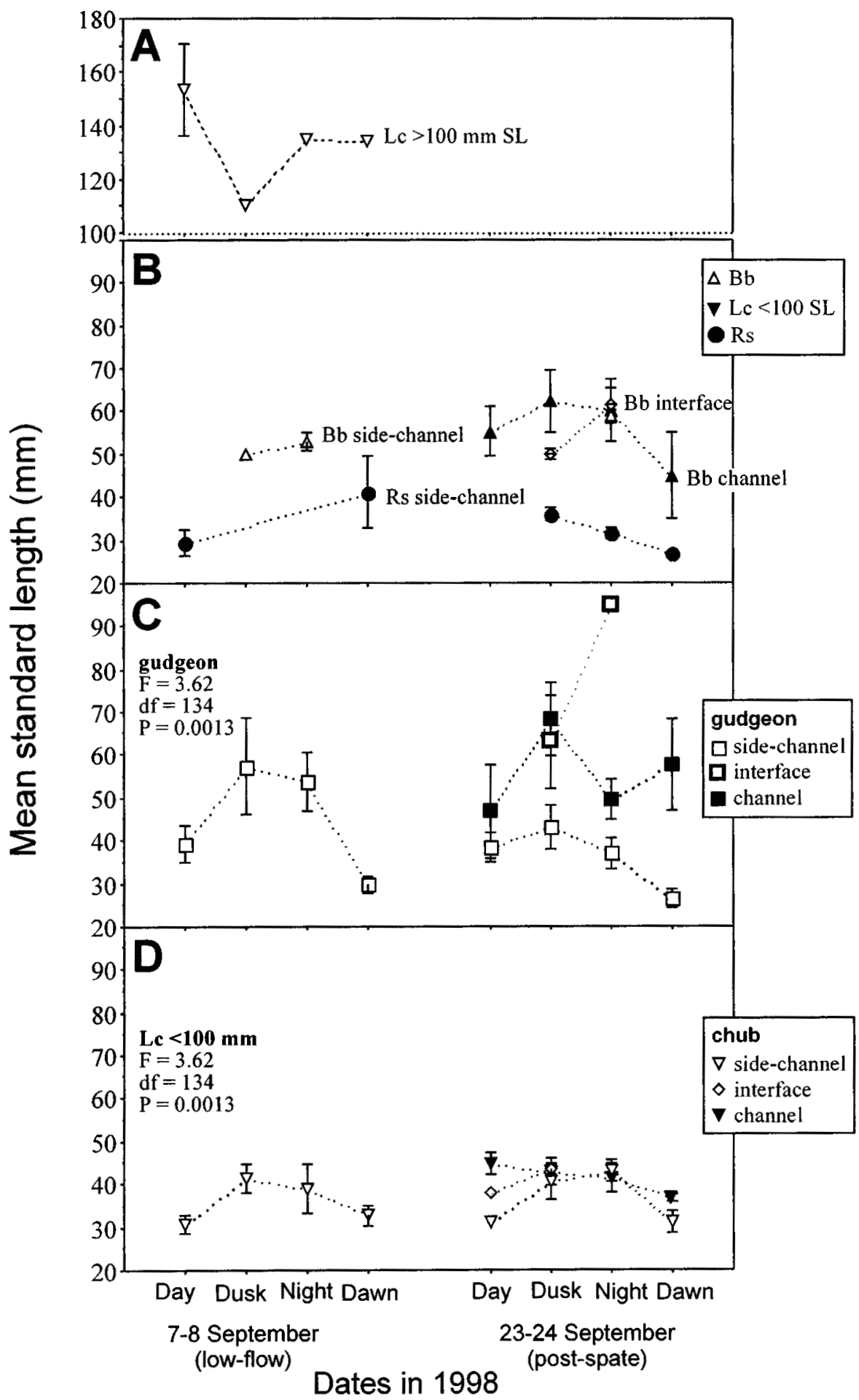

Fig. 4. Mean standard length (SL) of potential predators (A), chub (Lc) $>100 \mathrm{~mm}$ SL, of other species (B) and in particular gudgeon (C) and non-piscivorous chub, $<100 \mathrm{~mm} \mathrm{SL} \mathrm{(D),} \mathrm{by} \mathrm{mesohabitat} \mathrm{in} \mathrm{the} \mathrm{River}$ Garonne during late summer of 1998 . 

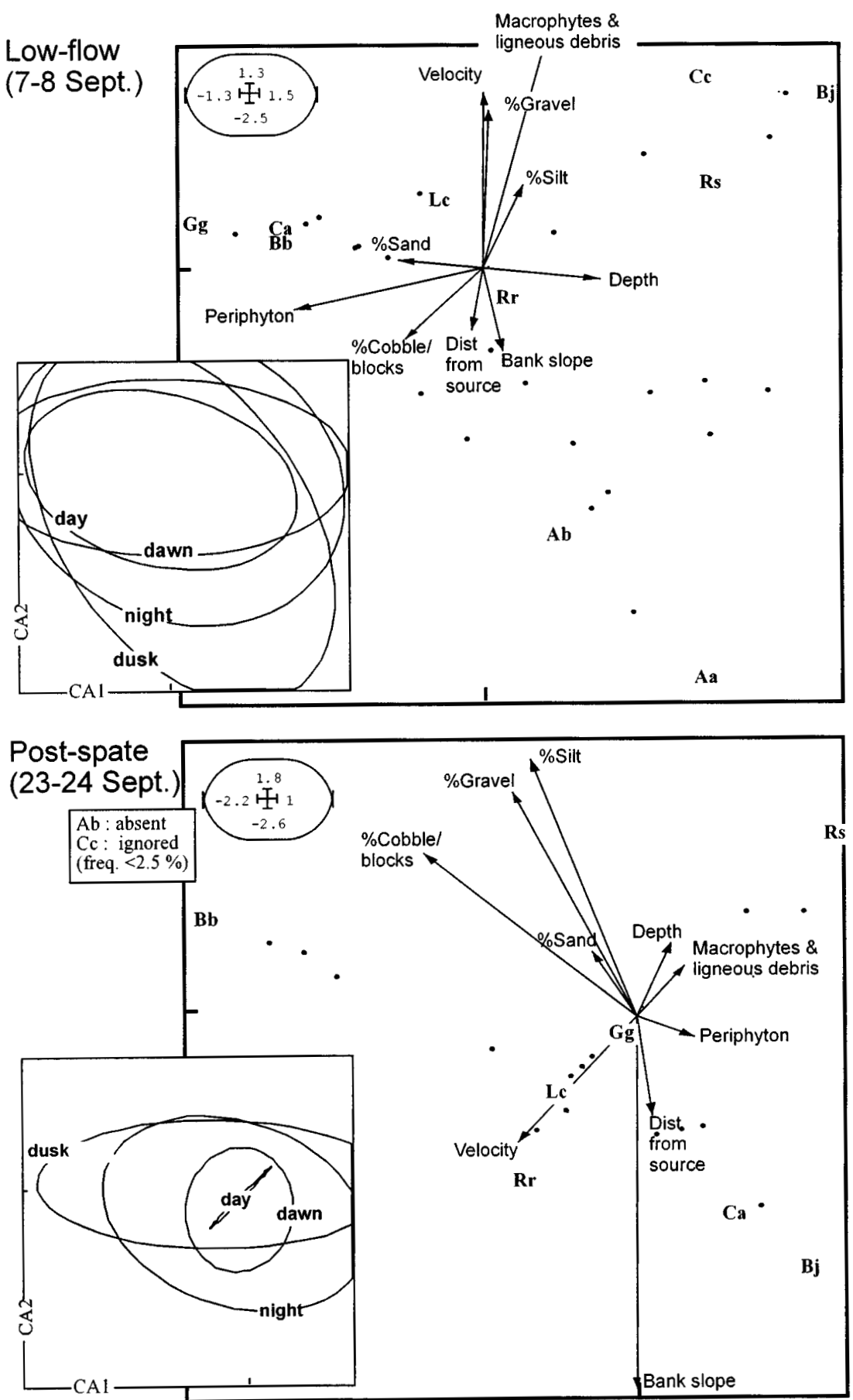

Fig. 5. Canonical correspondence triplots of species, samples and habitat variables relationships during low-flow and post-spate periods in a side channel of the River Garonne (main channel and interface samples of 23-24 September excluded). Given as an inset are the samples plots with $90 \%$ ellipses (Green 1971) for samples from the four intervals of day examined. 


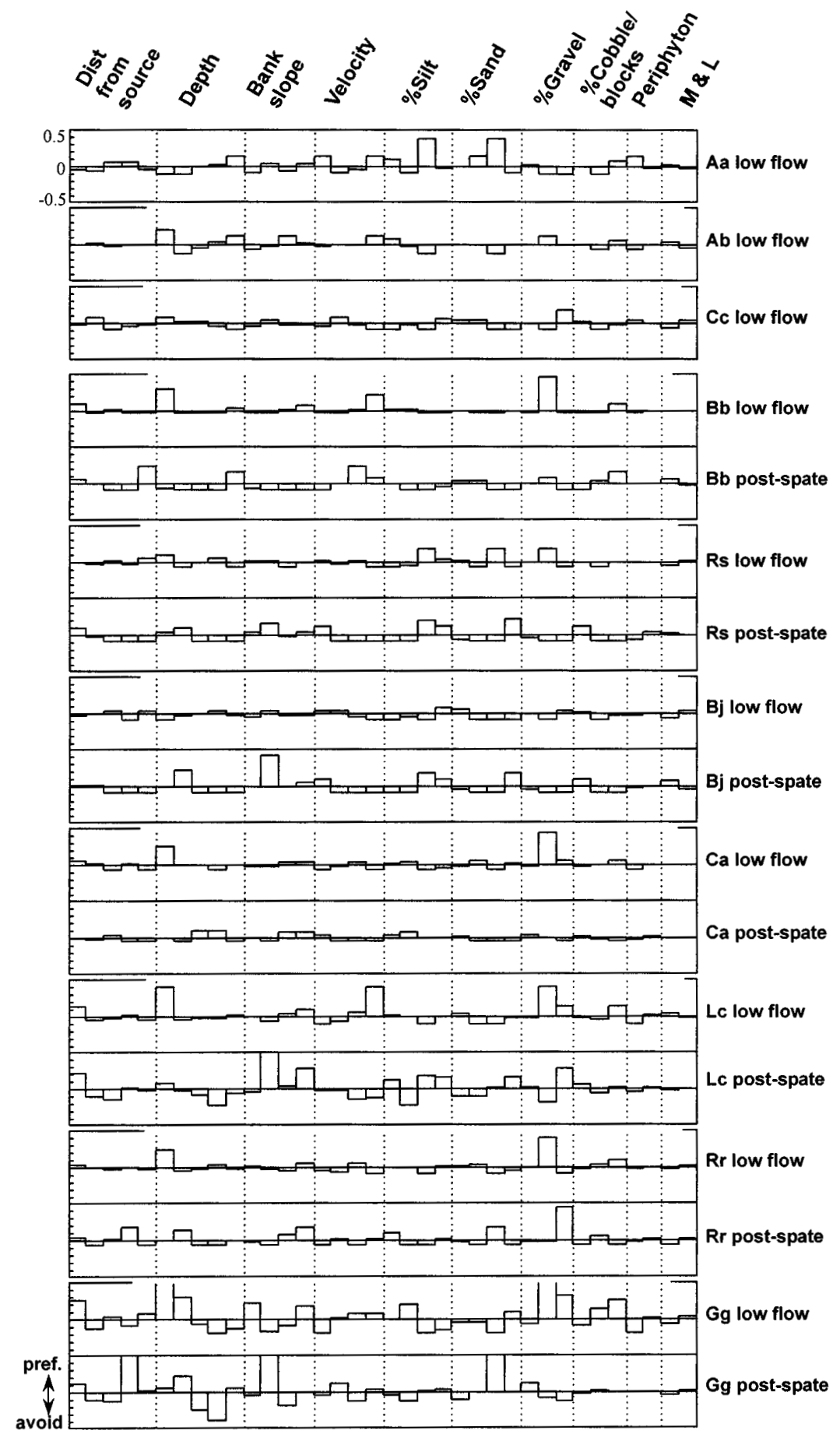

Fig. 6. Microhabitat electivity profiles for young fishes in a side-channel of the River Garonne during lowflow prior (7-8 September) and post (23-24 September) spate in 1998. The bar graphs represent the difference between the frequency of that species in the group of samples having that category of environmental variable and the frequency of that species in all the samples. Preference and avoidance are indicated by values approaching +0.5 and -0.5 , respectively. 


\section{Discussion}

The absence of a diel pattern in fish density during low-discharge conditions (7-8 Sept.) in our study (Fig. 3 ) resembles that reported by Schröder (1979) for a side channel of the River Rhine (Germany) when an artificial light source was used during sampling. Our results also resemble those observed in a side channel of the River Danube (Copp, Vranovsky, Cerny \& Kovác, unpublished) under the relative brightness of a waxing gibbosus moon. This contrasts the increased numbers of fishes generally observed at dusk and/or night in lakes (Hanych et al. 1983, Tischler et al. 2000), reservoirs (Vostradovsky 1965, Vasek et al. 2000), and in small (Bischoff \& Scholten 1996, Copp et al. 2005) and medium-sized rivers (Sanders 1992, Copp \& Jurajda 1993, 1999, Garner 1996, Baras \& Nindaba 1999, 2000).

However, the significant diel variations in size of $0+$ gudgeon and chub (Fig. 4) in the Garonne side-channel during the first $24-\mathrm{h}$ period clearly suggests a diel migration of larger individuals into the backwater from elsewhere. Emergence of fish from places within the backwater inaccessible to electrofishing is unlikely as none of the latter were apparent to us. There was no evidence of dispersion (of day-time shoals) in the evening as observed in lakes (Tischler et al. 2000) and some rivers (Copp, Vranovsky, Cerny \& Kovác, unpublished), but nocturnal clumping was apparent in $0+$ barbel similar to that observed in the River Lee, England (Copp, Spatari \& Turmel 2005).

The appearance of diel density patterns in the Garonne side-channel and its interface with the main channel (Fig. 3) after the spate emphasizes the influence of hydrological and illumination (stochastic) factors on fish behavioural patterns and the potential influence on predator-prey interactions, e.g. no predatory chub were observed in the samples collected after the spate, when moonlight levels were very low. This absence of predators should not be due to the difference in the sampling protocol, as the transects of point samples encompassed the same range of microhabitats (muddy and alluvial shallows, vegetated and vegetation-free areas, etc.), as did the entirely haphazard sampling of the pre-spate excursion. The most remarkable influence of the spate on microhabitat use appears to be the notable reduction in day-time variation along a strong velocity gradient (Fig. 5). Equally important was the shift in overall dominant microhabitat variables from macrophytes/ligneous debris, periphyton and velocity to bank slope, alluvial composition of the bottom and water velocity.
In conclusion, diel patterns in fish size (increases in SL at night) remained generally unaffected by the spate, whereas an absence of diel pattern in fish density was replaced post-spate in some species by an increase at night - this perhaps due to the differences in moonlight during the sampling before (nearly full moon) and after (new moon) the spate. Microhabitat use was variable at dusk and night before and after the spate, but daytime and dawn microhabitat use was less variable after the spate. The importance of water velocity and physical structures (macrophytes and ligneous debris) prior to the spate was replaced thereafter by substratum composition and bank slope. The changes in electivity profiles were particularly apparent in the most abundant species, with $0+$ gudgeon shifting from shallow, bank-side alluvial areas close to somewhat deeper, sandy areas further from the bank. $0+$ chub continued to prefer shallows close to the bank, but shifted preferences from higher velocity areas with larger alluvial to low velocity, silty areas (Fig. 6). The vast differences in microhabitat electivities observed before and after the spate corroborate the assertion of Mathur et al. (1985) that habitat suitability (or preference) curves and electivity profiles can vary day-today (Fig. 6), day vs. night (Roussel et al. 1999, also Vilizzi \& Copp, unpublished) and between streams of the same river catchment (Copp \& Vilizzi 2004) with variations in environmental conditions.

\section{Acknowledgements}

The study was funded by the French National Wetlands Programme (PNRZH Garonne). We thank P Marty and A. Soulard for assistance in the field and laboratory.

\section{References}

Baras E. \& Nindaba J. 1999. - Diel dynamics of habitat use by riverine young-of-the-year Barbus barbus and Chondrostoma nasus (Cyprinidae). Arch. Hydrobiol., 146, 431-448.

Baras E. \& Nindaba J. 2000. - Seasonal and diel utilisation of inshore microhabitats by larvae and juveniles of Leuciscus cephalus and L. leuciscus. Env. Biol. Fish., 56, 183-197.

Belaud A. Bengen D. \& Lim P. 1990. - Approche de la structure du peuplement piscicole de six bras morts de la Garonne. Ann. Limnol. - Int. J. Lim., 26, 81-90.

Bengen D. 1992. - Contribution à la typologie fonctionnelle des bras morts de la Garonne, approches physico-chimique et ichtyologique. Ph.D. thesis. Toulouse, France : Institut National Polytechnique de Toulouse. $164 \mathrm{p}$.

Bischoff A.B. \& Scholten M. 1996. - Diurnal distribution patterns of 0+barbel Barbus barbus (L) in two different types of habitats in the River Sieg. Germany. Folia Zool., 45 (Suppl. 1), 13-20.

Bischoff A.B. \& Wolter C. 2001. - The flood of the century on the River Oder : effects on the $0+$ fish community and implications for floodplain restoration. Regul. River. 17, 171-190.

Copp G.H. 1989a. - Electrofishing for fish larvae and 0+ juveniles : equipment modifications for increased efficiency with short fishes. Aquaculture \& Fisheries Management, 20, 177-186. 
Copp G.H. 1989b. - The habitat diversity and fish reproductive function of floodplain ecosystems. Env. Biol. Fish., 26, 1-26.

Copp G.H. \& Penáz M. 1988. - Ecology of fish spawning and nursery zones in the flood plain, using a new sampling approach. $\mathrm{Hy}$ drobiologia, 169, 209-224.

Copp G.H. \& Garner P. 1995. - Evaluating microhabitat use of fish larvae and juveniles with Point Abundance Sampling. Folia Zool., 44, 145-158.

Copp G.H. \& Jurajda P. 1993. - Do small fish move inshore at night ? J. Fish Biol., 43 (Suppl. A), 229-241.

Copp G.H. \& Jurajda P. 1999. - Size-structured diel use of banks by riverine fishes. Aquat. Sci., 61, 75-91.

Copp G. H., Spathari S. \& Turmel M. 2005 - Consistency of diel behaviour and interactions of stream fishes and invertebrates during summer. River Res. Appl. 21.

Copp G. H. \& Vilizzi L.2004. - Spatial and ontogenetic variability in the microhabitat use of stream-dwelling spined loach (Cobitis taenia) and stone loach (Barbatula barbatula). J. Applied Ichthyology, 20, 440-451

Décamps H. \& Naiman R.J. 1989. - L'écologie des fleuves. La recherche, 208, 310-319.

Elliot J. M. 1977. - Some methods for the statistical analysis of samples of benthic invertebrates. Freshwater Biol. Assoc. Sci. Publ. $25.144 \mathrm{p}$.

Garner P. 1996. - Diel behaviour of juvenile 0-group fishes in a regulated river : The Great Ouse, England. Ecol. Freshwat. Fish, 5, 175-182.

Gozlan R., Mastrorillo S. Dauba F., Tourenq J.N. \& Copp G.H. 1998. - Multi-scale analysis of habitat use by 0+ fishes during late summer in the River Garonne (France). Aquat. Sci., 59, 1-19.

Green R. H. 1966. - Measurement of non-randomness in spatial distributions. Res. Popul. Ecol., 8, 1-7.

Green R.H. 1971. - A multivariate statistical approach to the Hutchinsonian Niche : bivalve molluscs of central Canada. Ecology, 52, 543-556.

Hammer C. 1985. - Feeding behaviour of roach (Rutilus rutilus) larvae and the fry of perch (Perca fluviatilis) in Lake Lankau. Arch. Hydrobiol, 103, 61-74.

Hanych D.A., Ross M.R., Magnien R.E. \& Suggars A.L. 1983. Nocturnal inshore movement of the mimic shiner (Notropis volucellus) : a possible predator avoidance behaviour. Can. J. Fish. Aquat. Sci., 40, 888-894.

Mann R.H.K. 1976. - Observations on the age, growth, reproduction and food of the chub Squalius cephalus (L.) in the River Stour, Dorset. J. Fish Biol., 8, 265-288.

Manteifel B.P., Girsa I.I. \& Pavlov D.S. 1978. - On rhythms of fish behaviour. In : J.E. Thorpe (ed.) On Rhythms of Fish Behaviour. New York: Academic Press. p. 215-224.

Mathews C.P. 1971. - Contribution of young fish to total production of fish in the River Thames near Reading. J. Fish Biol., 3 : 157 180 .
Mathur D., Bason W.H., Purdy E.J. jr. \& Silver C.A. 1985. - A critique of the Instream Flow Incremental Methodology. Can. J. Fish. Aquat. Sci., 42, 825-831.

Pavlov D.S. 1994. - The downstream migration of young fishes in rivers : mechanisms and distribution. Folia Zool., 43, 193-208.

Pavlov D.S., Pakhorukov A.M., Kuragina G.N., Nezdoliy V.K., Nekrasova N.P., Brodskiy D.A. \& Ersler A.L. 1978. - Some features of the downstream migrations of juvenile fishes in the Volga and Kuban Rivers. Journal of Ichthyology, 19, 363-374.

Penáz M. 1975. - Diel lokomotorische Aktivitat larvaler und juveniler Elritzen (Phoxinus phoxinus). Zoologica Listy, 24, 263-276.

Przybylski M. 1996. - The diel feeding pattern of bitterling, Rhodeus sericeus amarus (BLOCK) in the Wieprz-Krzna Canal, Poland. Polish Archives of Hydrobiology, 43, 203-212.

Roussel J.-M. \& Bardonnet A. 1999. - Ontogeny of diel pattern of stream-margin habitat use by emerging brown trout, Salmo trutta in experimental channels : influence of food and predator presence. Env. Biol. Fish., 56, 253-262.

Roussel J.-M., Bardonnet A. \& Claude A. 1999. - Microhabitats of brown trout when feeding on drift and when resting in a lowland salmonid brook : effects on Weighted Usable Area. Arch. Hydrobiol, 146, 413-429.

Sanders R.E. 1992. - Day versus night electrofishing catches from near-shore waters of the Ohio and Muskingum Rivers. Ohio Jour nal of Science, 92, 51-59.

Schröder T. 1979. - Aspecte der Okologie von Frühentwicklungsstadien einiger Fischarten in Altrhein und Labor. Diplomarbiet (M. Sc. Thesis) Frankfurt am Main. 100 p.

ter Braak C.J.F. 1986. - Canonical Correspondence Analysis : a new eigenvector technique for multivariate direct gradient analysis. Ecology, 67, 1167-1179.

ter Braak C.J.F. \& Verdonschot P.F.M. 1995. - Canonical correspondence analysis and related multivariate methods in aquatic ecology. Aquat. Sci., 57, 1015-1621.

Thioulouse J. 1990. - MacMul and GraphMu: two Macintosh programmes for the display and analysis of multivariate data. Comp Geosci., 8, 1235-1240.

Thioulouse J. \& Chessel D. 1992. - A method for reciprocal scaling of species tolerance and sample diversity. Ecology, 73, 670-680.

Tischler G., Gassner, H, \& Wanzenböck J. 2000. - Sampling characteristics of two methods for capturing age- 0 fish in pelagic lake habitats. J. Fish Biol., 57, 1474-1487.

Vasek M., M. Cech, D. Dusek, M. Hladík, J. Kubecka, J. Matena, J. Peterka, P. Pokorny, M. Prchalová \& Stafa P. 2000. - Diurnal fluctuation of fish catches taken by pelagic gillnets in the Rímov Reservoir. In Mikesová, J. (ed), Proceedings IV Czech Ichthyological Conference. 10-12 May 2000, Vodnany: 35-40. (in Czech)

Vostradovsky J. 1965. - Some notes on the occurrence of fish fry along the banks of the Lipno Valley dam in the course of the day and night. Vyzkumny Ústav Rybarsky a Hydrobiologie Vodnany, 5, 221-230 (in Czech with English summary). 